Article

\title{
Effect of Operating Parameters on the Performance Evaluation of Benthic Microbial Fuel Cells Using Sediments from the Bay of Campeche, Mexico
}

\author{
Nancy González-Gamboa ${ }^{1}$, Xochitl Domínguez-Benetton ${ }^{2}$, Daniella Pacheco-Catalán ${ }^{1}$ (i), \\ Sathish Kumar-Kamaraj ${ }^{3}{ }^{(\mathbb{D})}$, David Valdés-Lozano ${ }^{4}$, Jorge Domínguez-Maldonado ${ }^{1}$ \\ and Liliana Alzate-Gaviria ${ }^{1, *}$ \\ 1 Renewable Energy Unit, Yucatan Center for Scientific Research (CICY), \\ Carretera Sierra Papacal-Chuburná Puerto Km 5, Sierra Papacal 97302, Yucatán, Mexico; \\ karina.gonzalez@cicy.mx (N.G.-G); dpacheco@cicy.mx (D.P.-C); joe2@cicy.mx (J.D.-M) \\ 2 Separation and Conversion Technologies, VITO-Flemish Institute for Technological Research, Boeretang 200, \\ 2400 Mol, Belgium; xoch@vito.be \\ 3 Laboratorio de Cultivo de Tejidos Vegetales, Instituto Tecnológico el Llano Aguascalientes (ITEL), \\ Tecnológico Nacional de México (TecNM), Aguascalientes, Km 18 Carr. Aguascalientes-San Luis Potosí, \\ El Llano, Ags. C.P. 20330, Mexico; sathish.bot@gmail.com \\ 4 Marine Chemistry Laboratory, Center for Research and Advanced Studies, \\ National Polytechnic Institute Mérida Unit, Carretera Antigua a Progreso Km 6, \\ Mérida 97310, Yucatán, Mexico; dvaldes@mda.cinvestav.mx \\ * Correspondence: lag@cicy.mx; Tel.: +52-(999)-942-8330
}

Received: 20 April 2018; Accepted: 22 June 2018; Published: 13 July 2018 updates

\begin{abstract}
Benthic microbial fuel cells (BMFC) are devices that remove organic matter (OM) and generate energy from sediments rich in organic nutrients. They are composed of electrodes with adequate different distances and floating air cathodes in an aqueous medium with saturated oxygen. In this study we proposed to design, build, analyze and evaluate a set of BMFCs with floating air cathodes to test the optimal distance between the electrodes, using sediment from the Bay of Campeche as a substrate. For the analysis of OM removal, COD tests, volatile solids (VS), $\mathrm{E}_{4} / \mathrm{E}_{6}$ study and FTIR analysis were performed. Power generation was evaluated through polarization curves, cyclic voltammetry and electrochemical impedance spectroscopy (EIS). We achieved a current density and power density at $10 \mathrm{~cm}$ depth of $929.7 \pm 9.5 \mathrm{~mA} / \mathrm{m}^{2}$ and $109.6 \pm 7.5 \mathrm{~mW} / \mathrm{m}^{2}$ respectively, with $54 \%$ removal of OM from the sediment, obtaining formation of aliphatic structures. BMFCs are proposed as adequate systems for bioremediation and power generation. The system at $10 \mathrm{~cm}$ depth and $100 \mathrm{~cm}$ distance between sediment and the floating air cathode had a good performance and therefore the potential for possible scaling.
\end{abstract}

Keywords: benthic microbial fuel cell; organic matter; floating air cathodes

\section{Introduction}

In Mexico there is a high level of pollution of marine resources, especially in the Bay of Campeche, where according to reports from the Autonomous University of Campeche, the National Autonomous University of Mexico, the Secretary of Marine and Natural Resources (SEMARNAT) and the Secretary of Urban Development and Environment (SEDUMA), there are high levels of Organic Matter (OM), mainly due to anthropogenic factors [1]. Because of this, current research has focused on the mitigation and reduction of OM, composed mainly of humic substances classified according to their solubility in aquatic environments: humic acids (HA) and fulvic acids (FA) and thus, indirectly, on the improvement 
of quality of life on our planet [2,3]. HA are the most resistant fraction in the microbial degradation of OM, composed mainly of aromatic groups; FA have lower molecular weight, more oxygen but less carbon and nitrogen and are formed of organic acids, phenolic compounds and mainly aliphatic compounds [4-6]. There are different bioremediation technologies that help to reduce the OM content and improve the sediment conditions and benthic microbial fuel cells (BMFC) could be an option. These are devices where the anodic electrode is buried in the anaerobic sediment and the cathode electrode suspended in the aerobic water column [7].

The performance of the BMFCs can be affected by different factors such as the distance between the electrodes [8-12], the anode depth in the sediment [12-15] and the reduction reaction in the cathode [16-20], because the implementation of these systems has been proposed on a real scale [21-23]. One of the first studies in which it was observed that the distance between the electrodes affects the performance of the BMFCs was carried out by Ghangrekar and Shinde et al. (2007) [8]. Hong et al. (2009) found that the current density depends on the space between the electrodes, varying the distance of the aqueous cathode between 12, 20, 80 and $100 \mathrm{~cm}$; obtaining 11.5, 7.64, 2.51 and $2.11 \mathrm{~mA} / \mathrm{m}^{2}$ respectively; and finding that the power density increases when the electrode gap decreases from 0.37 to $1.01 \mathrm{~mW} / \mathrm{m}^{2}[9,11]$.

The reactions at the anode do not occur equally in all layers of the sediment. In general, the boundary between water and sediment is under oxygen-rich conditions and this diffuses in the sediment where OM is aerobically consumed based on the aerobic respiration of heterotrophic microorganisms, which are mainly at a depth of $0.5 \mathrm{~cm}$ from the surface of the sediment and decreasing with respect to the depth. Then the oxygen levels decrease relatively as the depth of the sediment increases, producing a series of electron acceptors such as $\mathrm{NO}_{3}{ }^{-}, \mathrm{NO}_{2}{ }^{-}$, metal oxides, $\mathrm{SO}_{2}{ }^{-4}$ and $\mathrm{CO}_{2}$. The electronic exchange at the anode in the bottom side can be affected by organisms that prefer to consume $\mathrm{O}_{2}, \mathrm{NO}_{3}{ }^{-}, \mathrm{NO}_{2}{ }^{-}$, which are thermodynamically favorable as acceptors in the sediment, resulting in a decrease in the anode yield. This behavior can be improved if the electrode is placed at a depth where anodophilic and electrophilic species, such as bacteria that reduce metals or sulfate, are present (Redox potential where sulfate-reducing bacteria are found: $-240 \mathrm{mV}$ ). The concentration of substances varies from sediment to sediment depending on the environment, changing the concentrations of OM (0.4 to $2.2 \%)$ and microbial communities [15].

The low content of OM could be a limiting factor in the transfer of mass in a BMFC, decreasing the density of current and power generated [24]. Some research groups such as those of Lowy and Tender et al. (2008) [25] treated anodic electrodes with anthraquinone 1,6-disulfonic acid to improve the redox reaction of sulphides and sulfates. Rezaei et al. (2007) also added chitin to the substrate to compensate for the small amount of OM. Microbial activity in the sediments is often limited by the lack of organic substrates [26].

Likewise, it has been observed that in the cathode, the concentration of oxygen decreases with respect to the depth at which it is located [27]. Some authors such as Reimers et al. (2001) and Tender et al. (2008) observed that the oxygen in the aqueous cathode is limited by the submerged electrode, generating a maximum power density of 10 and $16 \mathrm{~mW} / \mathrm{m}^{2}$ respectively [12,21]. Therefore, this performance has been limited mainly by the oxygen reduction reaction at the aqueous cathode due to the poor kinetics of the reaction at neutral $\mathrm{pH}$, which is why some authors propose the use of aerated cathodes for BMFC, where the oxygen flow is 3.7 times higher than in an aqueous cathode $[10,16,23,28-30]$. These air cathodes are composed of three layers: the first is the collector in which electrons are received from the anode through the external circuit, the second is the catalyst which promotes the reduction reaction at the cathode and the third layer is the diffuser, which allows the reaction, improving the conditions of evaporation and substrate consumption [18,31].

Finally, Dumas et al. (2008) proposed using stainless steel mesh (SSM) as a current collector since it is an economical material, it can be used for large areas and it has adequate conductivity characteristics. They used zinc as a catalyst to help the formation of the biofilm during the start-up phase of the BMFC, generating a maximum power and current density of $60 \mathrm{~mW} / \mathrm{m}^{2}$ and $1890 \mathrm{~mA} / \mathrm{m}^{2}$ respectively [32]. 
In this study, it was proposed to improve the performance of the BMFC with floating air cathodes of stainless steel mesh with electrodeposition of $\mathrm{Zn}-\mathrm{Ni}-\mathrm{Co}$ at 4 distances of separation between the cathode and anode (buried inside the sediment: 5, 10, 50 and $100 \mathrm{~cm}$ ) and to evaluate the anodic electrodes at two depths of sediment $(5$ and $10 \mathrm{~cm}$ ), in order to obtain the best operating parameters.

\section{Materials and Methods}

\subsection{Sampling Collection}

Sediment samples were collected from the Bay of Campeche (OM: 9\%) at coordinates N19 $51^{\prime} 43.7^{\prime \prime}$ and $\mathrm{W} 90^{\circ} 31^{\prime} 0.01^{\prime \prime}$ during the rainy season (Rain) and cold fronts from North America (North). The sediment samples were collected with a Van Veen ${ }^{\circledR}$ dredge and stored in plastic buckets. The water was collected in plastic containers corresponding to each of the sampling points. The samples were taken to the CICY renewable energy laboratory, where they were finally stored in the cold room before the laboratory-scale prototypes were assembled [33].

\subsection{Construction of Electrodes and Support}

\subsubsection{Cathode Electrode Collector}

The stainless-steel mesh of the aerated cathode electrode $\left(50 \times 50 \mathrm{in}^{2}\right)$ received an electrodeposition (SSME) with an electrolyte of $0.20 \mathrm{M} \mathrm{ZnSO}_{4}, 0.20 \mathrm{M} \mathrm{NiSO}_{4}, 0.20 \mathrm{M} \mathrm{CoSO}_{4}, 0.20 \mathrm{M} \mathrm{Na}_{2} \mathrm{SO}_{4}$, $0.20 \mathrm{M} \mathrm{H}_{3} \mathrm{BO}_{3}, 0.01 \mathrm{M} \mathrm{H}_{2} \mathrm{SO}_{4}$. The steel mesh was previously polished with water sandpaper and washed with alcohol and then the mesh was immersed in the electrolyte. A chronopotentiometry was performed at $10 \mathrm{~mA}$ with respect to the Calomel reference electrode for $1 \mathrm{~h}$. Then Tafel tests were carried out in the seawater, used as an electrolyte in the BMFC, to establish the corrosion potential of the mesh, in order to protect the material from corrosion by seawater with high salt concentrations that favor oxidation of the material, as shown in Figure 1a [34,35].

\subsubsection{Floating Air Cathode}

The floating air cathodes were constructed with a SSME of $7 \mathrm{~cm}$ in diameter as shown in Figure 1a, then $100 \mathrm{mg}$ activated carbon (AC) (Carbotecnia, El Tigre, Jalisco, Mexico) and $10 \mathrm{mg}$ Carbon Black (CB) (Química Rana S.A. de C.V., Coyoacan, Mexico) were mixed in a vial for each $7 \mathrm{~cm}^{2}$ of cathode and homogenized in a vortex for $5 \mathrm{~min}$. After that, $12.6 \mu \mathrm{L}$ of PTFE (Sigma-Aldrich, Cd Mexico, Mexico) to $60 \%$ and $233.3 \mu \mathrm{L}$ of deionized water were added to the vial, followed by a $5 \mathrm{~min}$ ultrasound to form a paste. This paste was placed on the SSME as shown in Figure 1b [31]. The support was constructed with PVC as shown in Figure 1 where (c) serves as the base for the structure of the electrode, (d) is placed on top, then the Nafion ${ }^{\circledR}$ membrane and electrode are placed so that the AC-CB face is on the membrane, then the electrode is pressed by placing (e) and finally the system is closed with (f).

\subsubsection{Anode Electrode}

The anode electrode was constructed with a stainless steel mesh $(400 \times 400)$ (Sistemas de Ingeniería Integral DoGu S.A. de C.V., Cd Mexico, Mexico) and placed inside granular activated carbon $(4.81 \mathrm{~g})$ with a diameter of $5 \mathrm{~cm}$ as shown in Figure $1 \mathrm{~g}$. Both electrodes were connected with stainless steel cables supported by a PVC structure as shown in Figure $1 \mathrm{~h}$.

The structure of the BMFC was made with PVC material and comprised 4 columns that support two horizontal platforms of the same material, with a dimension of $18 \mathrm{~cm}$ from column to column as shown in Figure 1h. The height of the structures was calculated with respect to the separation between electrodes $[10,15,36,37]$. 


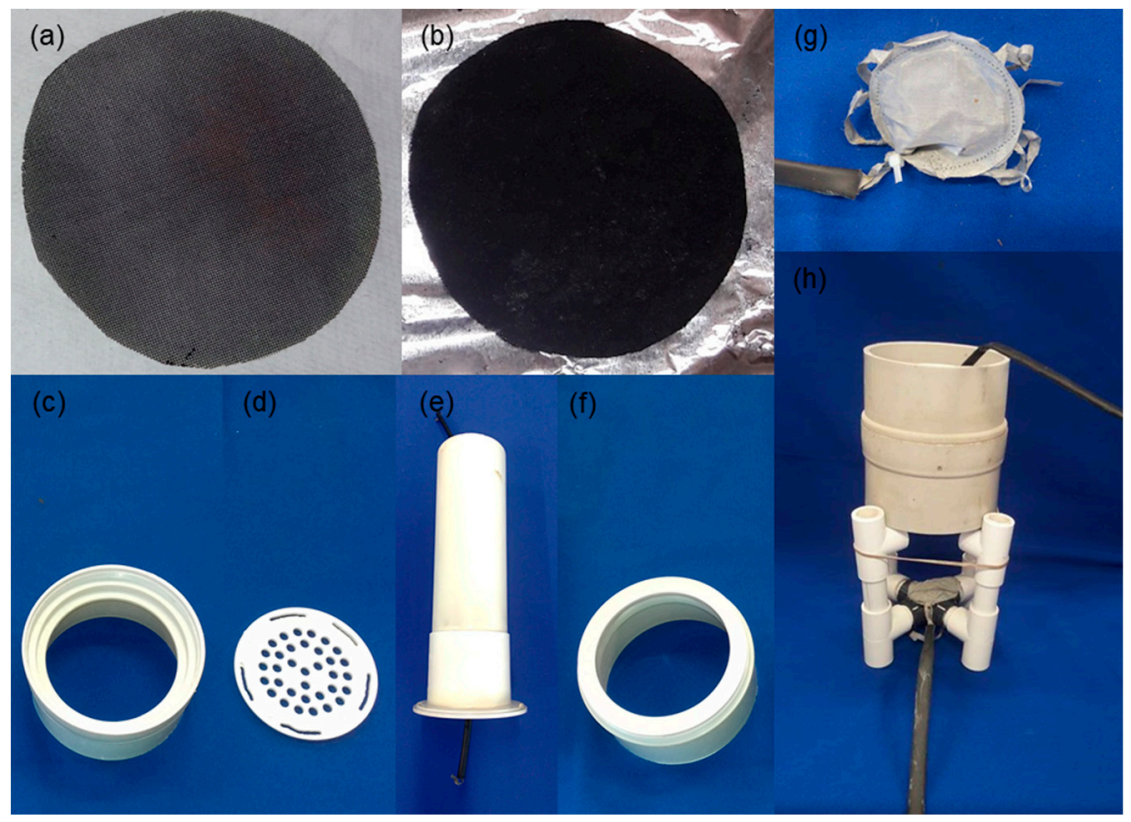

Figure 1. (a) SSM with electrodeposition; (b) SSME with AC-CB; (c) base for the electrode structure; (d) base on which the electrode is located; (e) lid that serves to press the electrode; (f) electrode seal; (g) Anode electrode; (h) structure of BMFC with assembled electrodes.

\subsection{Depth in Sediment and Distance between Electrodes}

The depths in the sediment at which the anode electrode was evaluated were 5 and $10 \mathrm{~cm}[12,15,21,27,38]$. The distances at which the floating air cathode electrode was placed on the surface of the sediment were 5, 10, 50 and $100 \mathrm{~cm}$ as shown in Figure 2 [10,12,21,27,38,39].

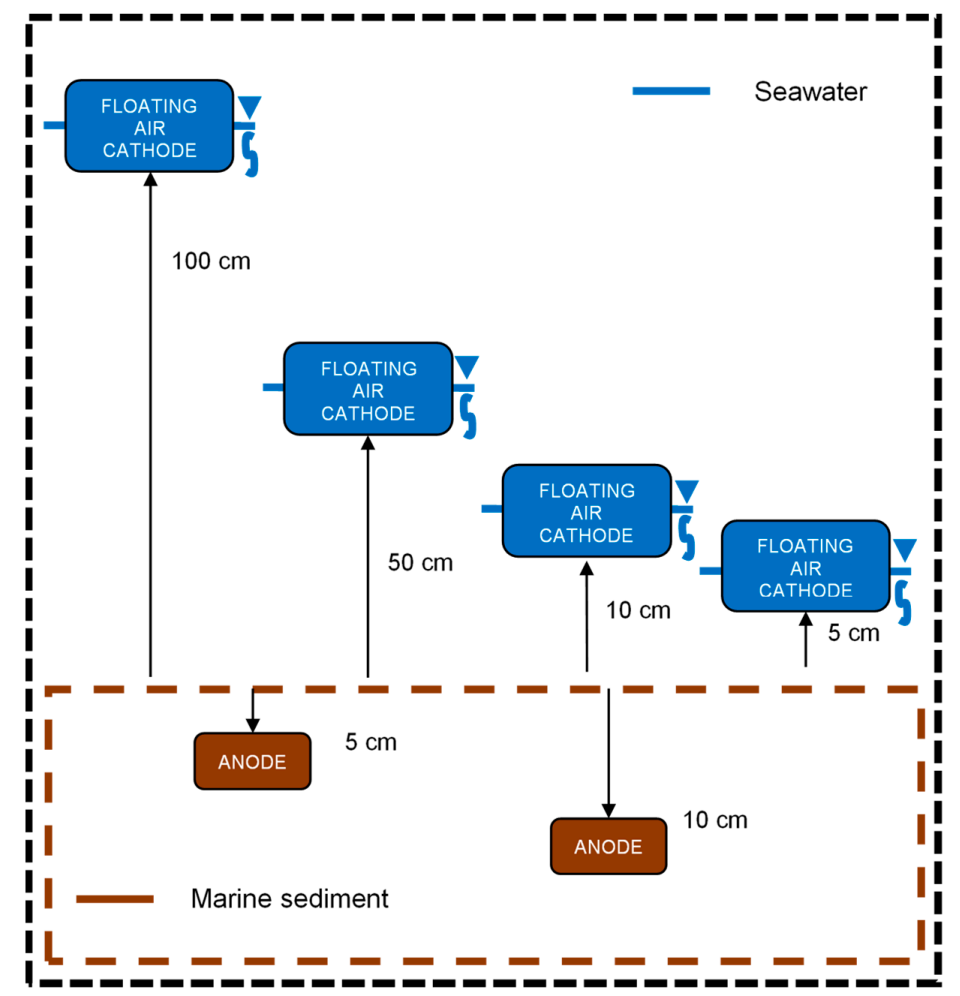

Figure 2. BMFC diagram with different distances between floating air cathode and anode depths. 


\subsection{Physicochemical Tests of Sediment and Water}

Analysis of OM content with volatile solids (VS) tests was carried out in accordance with Standard Methods [40]. Extractions of HA and FA were carried out for analysis of the behavior of aromatic and aliphatic compounds in the sediment, according to the protocol of Kononova et al. (1966) [41], with the $\mathrm{E}_{4} / \mathrm{E}_{6}$ analysis in the absorbances of 465 and $665 \mathrm{~nm}$, for the identification of the HA and FA of the sediment. Finally, an analysis of Fourier Transform Infrared Spectroscopy (FTIR) was performed to determine the functional groups present in the sediment and their variation at the beginning and at the end of the experiment [33]. Analyses were carried out of the content of OM in the water with COD tests [40] at the beginning and end of the BMFCs evaluation month [42]. The COD was calculated according to the standardized Hach Colorimeter DR-890/8000 method. This method can present interference from chlorides and due to this, $0.5 \mathrm{~g}$ of mercury sulfate was added to the COD vial [42].

\subsection{Electrochemical Evaluation}

Cyclic voltammetry was performed using scanning speeds of 10, 20, 30, 40, $50 \mathrm{mV} / \mathrm{s}$, using as the working electrode a graphite bar, a reference electrode of Calomel and as counter electrode a Platinum coiled wire, in order to characterize the catalytic activity of the sediment [23,43]. Likewise, polarization curves and electrochemical impedance spectroscopy (EIS) tests were performed on the BMFC system, connecting the anode electrode as the working electrode (WE) and cathode as counter electrode (CE) and a reference electrode (RE), to observe the maximum density of current and power over time and to obtain the internal resistance of the system respectively, using the same configuration in the connection in the potentiostat. All BMFCs were closed circuit with a $5 \mathrm{~F}$ supercapacitor and were disconnected when performing the electrochemical tests.

\section{Results and Discussion}

\subsection{Physicochemical Tests}

\subsubsection{Volatile Solids (VS)}

In this study carried out with the substrate from the Bay of Campeche, OM was found to be $9 \pm 4.61 \%$, higher than the average reported by Chio and Kile et al. (2000) of $0.4-2 \%$ maximum in sites without pollution. This was attributed to anthropogenic activity, namely the release of the city's sewage directly into the bay, which affects tourism, the economy and the ecological environment. The Secretary of Environment and Natural Resources (Semarnat) and the Commission for Protection Against Health Risks (Copriscam) have pointed out that the lack of wastewater treatment plants causes the increase in pollution levels in the bay [24].

In this study, it was possible the effect of the distance between the electrodes to degrade from 51 to $54 \%$ of OM and we noted that most of the removal of OM was obtained in the BMFC with anodes at $5 \mathrm{~cm}$ depth. However, there is no significant difference in the percentage of removal with the anode electrode at $10 \mathrm{~cm}$ depth since at this depth a maximum removal of $52.89 \%$ was obtained, which is why it is concluded that at both depths a large amount of OM is removed, this quantity being greater than the percentage reported by other authors in sediments. This high percentage suggests the presence of electron donors or acceptors of methanol, nitrates and sulphates, which increase the efficiency of the removal of OM [44]. Gonzalez et al. (2017) evaluated sediments from Yucatan where the OM that was found was around 6.74 to $13.13 \%$, removing a maximum of $18 \% \mathrm{OM}$, which indicates that BMFC favor sedimentary bioremediation [45]. Zhou et al. (2015) removed 9\%, which was attributed to the design and configuration of the BMFC [46]. In this study, an increase in the removal of OM in the sediment was observed due to the presence of an anodic material with a large surface area for microorganisms, that is, activated carbon and also due to the fact that the BMFC had aerated cathodes, which favored the oxidation and reduction process [47]. 
Due to the influence of the cathode separation with respect to OM removal, it is proposed, based on this study, that BMFC could be placed at $100 \mathrm{~cm}$ of separation between electrodes in future applications of these systems on a real scale.

The content of OM in the sediment used in the study carried out by An et al. (2013) was 7.2\% and they observed that when placing a BMFC in a sediment with high organic load, a maximum potential is obtained of $0.26 \mathrm{~V}$ using a $1 \mathrm{k} \Omega$ external resistance, the anode being evaluated at different depths (from 2 to $10 \mathrm{~cm}$ ), obtaining the maximum power density and current at a depth of $10 \mathrm{~cm}$, similar to the figures obtained in this study [15].

It is important to mention that the fraction of sedimentary OM decreases exponentially with the increase in sediment depth and the increase of sediment may be due to anthropogenic activities, especially in areas of recent industrial activity [48].

Wang et al. (2012) removed $29 \%$ of OM from the marine sediment. This value is suggested to be due to the absence of bacteria with lower redox potential ( $-191 \mathrm{mV}$ with respect to hydrogen) present at the depth at which the anode electrode was buried in marine sediment, since these favor greater removal and generation of energy $[10,49]$. We concluded that this hardware favors the bioremediation of marine sediments with a greater density of power and current when placing the anode electrode between 5 and $10 \mathrm{~cm}$ depth.

\subsubsection{Variation of $E_{4} / E_{6}$ in the Application of BMFC}

The ratios of the absorbances of HA and FA are widely used for the characterization of materials in a soil. A low $\mathrm{E}_{4} / \mathrm{E}_{6}$ ratio indicates a high degree of condensation of aromatic structures while a high ratio reflects a low degree of aromatic condensation and implies the presence of relatively large proportions of aliphatic structures [41]. In this study, the HA and FA of the soil were found at a ratio of 5.9 and 3.8 respectively, which is why it is suggested that it is a podzol soil (characteristic of humid climates) [50]. An increase in the $\mathrm{E}_{4} / \mathrm{E}_{6}$ ratios in HA and FA was observed of 7.07 and 10 respectively after the sediments had been submitted to the BMFCs, indicating the degradation of aromatic compounds according to Bravo et al. (2007) and leading to the proposal that this change in OM is due to the presence of BMFCs and that the increase is explained by the fact that in the first 30 days of evaluation of the BMFC the microorganisms consume the easily degraded OM, as mentioned by Theng et al. (2012) [9,51,52].

This behavior was observed in the BMFC evaluated in the study by González et al. (2017), where an increase in the ratios of up to 6.7 in HA and 5.8 in FA was found during 120 days of evaluation, obtaining the degradation of aromatic compounds [45].

\subsubsection{Analysis of Fourier Transform Infrared Spectroscopy (FTIR)}

The FTIR spectra presented in Figure 3 show peaks between 3700 and $3500 \mathrm{~cm}^{-1}$ which correspond to the vibrations of $\mathrm{O}-\mathrm{H}$ and $\mathrm{N}-\mathrm{H}$, characteristic in sediments that are rich in nitrogen [53]. Peaks of 3400-3200 $\mathrm{cm}^{-1}$ (a) were observed, representing unions of $\mathrm{O}-\mathrm{H}$ due to the presence of phenols, acid groups and bands associated with hydrogen [54]. The absorbance peaks close to $2900 \mathrm{~cm}^{-1}$, $1475-1445 \mathrm{~cm}^{-1}$ and $730-710 \mathrm{~cm}^{-1}$ (b), (f), (i), were due to the vibrations of C-H aliphatic bands in $\mathrm{CH}_{3}$ and $\mathrm{CH}_{2}$ functional groups in the sediments and were slightly more defined after being evaluated in receipt of the BMFC. The pronounced bands indicate that the sedimentary OM has humification properties compared to the initial BMFC sediment as mentioned in Hong et al. (2009). The anaerobic oxidation of OM was evidenced in the signal peaks at $1200 \mathrm{~cm}^{-1}(\mathrm{~g})$ assigned to the carboxylic and phenolic groups. It is suggested that this increase of groups is due to the consumption of organic matter by microbial oxidation. The bands between 1725 and $1600 \mathrm{~cm}^{-1}(\mathrm{~d})$ and (e) are slightly stronger than at the beginning, showing that this change is typical of high molecular weight HA. The presence of signals in the peaks of 1650 to $1600 \mathrm{~cm}^{-1}$ (d) is attributed to an increase in aromatization, resulting in a change in OM by endogenous microorganisms under high reduction conditions. The physical and chemical properties of the OM of the sediments indicate a more humified sediment compared 
to the humus found in other studies [33]. The bands near to 1074 and $600 \mathrm{~cm}^{-1}(\mathrm{~h}),(\mathrm{m})$ and (n) are attributed to the stretching of polysaccharides or joint polysaccharide components or impurities of silicates, $\mathrm{Si}-\mathrm{O}$ and vibrations associated with unknown mineral compounds. It should be noted that after 30 days of evaluation the peak increased, indicating the mineralization of the material [55].

In the FA spectrum, close bands were observed between 3400 and $3200 \mathrm{~cm}^{-1}(\mathrm{j})$ corresponding to alcohol and phenol O-H polymer association. The peaks at $2300 \mathrm{~cm}^{-1}(\mathrm{k})$ represent triple nitrile bonds. The peaks at $1650 \mathrm{~cm}^{-1}$ (l) correspond to the increase of aromatic structures with respect to the beginning of the evaluation of the sediment, coinciding with the response of the HA, an increase being observed in both HA and FA of aromatic compounds [53].

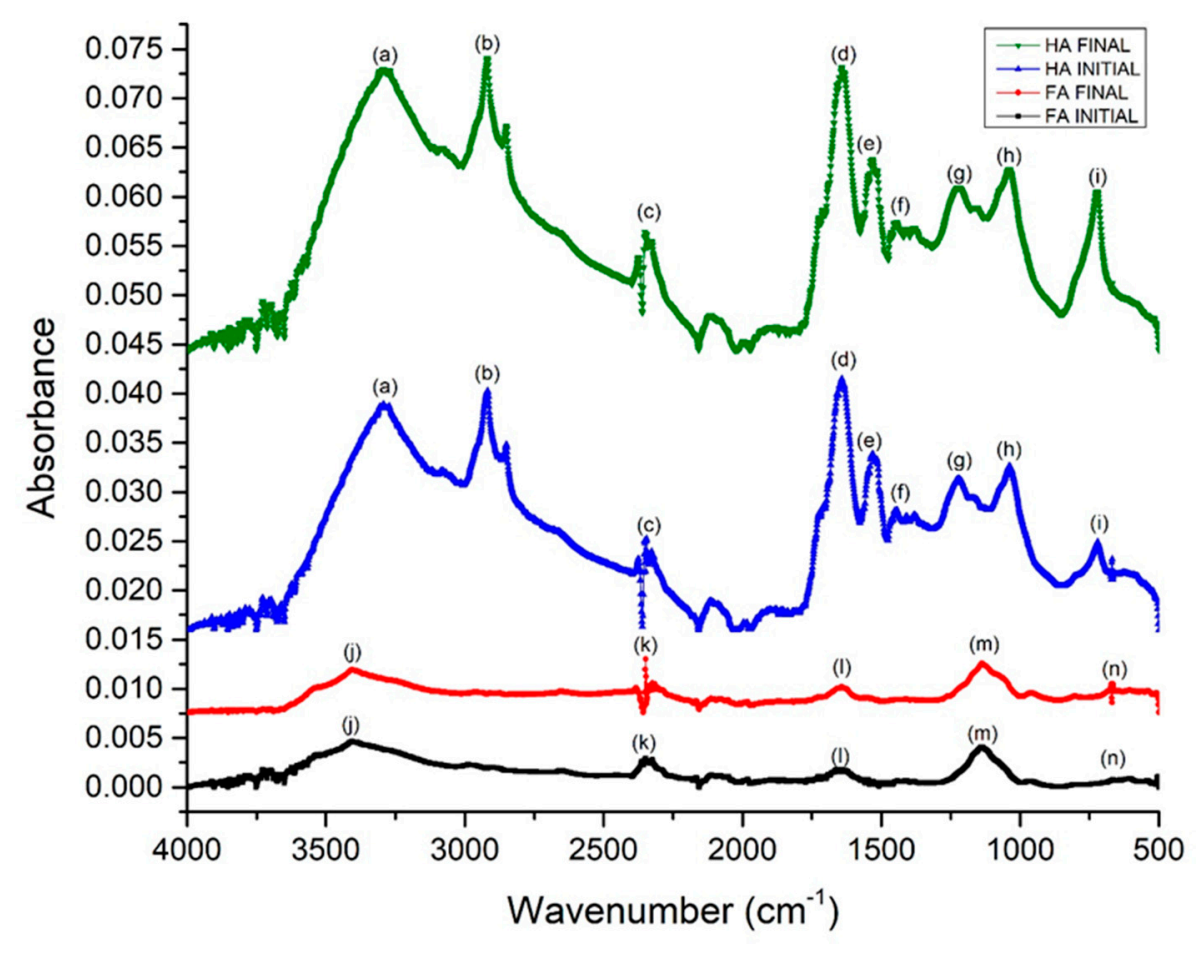

Figure 3. FTIR of humic acids (HA) and fulvic acids (FA) (peak descriptors in the text).

\subsubsection{Chemical Oxygen Demand (COD)}

The chemical oxygen demand (COD) is an important reference in the quality of water management and infections in local communities around the Bay of Campeche have been reported because of the growing level of contamination [56].

In this study we identified that the marine water of the Bay of Campeche is at $1290 \mathrm{mg} / \mathrm{L} \mathrm{COD,}$ the content of organic material being higher than that reported in the black and gray waters, where 1010 and $370 \mathrm{mg} / \mathrm{L}$ respectively were found, while that of domestic wastewater is at $440 \mathrm{mg} / \mathrm{L}$ [57]. However, for the use and disposal of water according to the Standard, a COD of 100-120 mg/L should be achieved, according to the SEMARNAT as reported in sanitation standards (NOM-001). This represents a great opportunity for the installation of BMFC because they are known to be bioremediation systems.

The concentration of COD can vary more significantly in sites near the coasts than at locations near the open sea. Also, COD concentrations can be significantly higher in the spring-summer season than in autumn-winter, which is attributed to rainfall [58].

The removal of OM in saline water reached $9 \%$ COD, going as high as $1170 \mathrm{mg} / \mathrm{L}$, based on the removal of OM on the surface of the BMFC. Sajana et al. (2017) removed 79\% of COD in a BMFC, the quantity being evaluated in the band that lies between the sediment and seawater, generating 
a power density of $15 \mu \mathrm{W} / \mathrm{m}^{2}$ and thus evaluating the OM precipitated in the column of water to the sediment. This coincides with what was proposed by Lein et al. (2012), who observed that in waters and oceans, energy and matter are transformed mainly at the interface of the water column and the bottom of the sediment. Suspended particulate matter and components dissolved in seawater enter the top of the water column and have their termination in sedimentation. The source of energy for the biogeochemical processes at the sediment-water junction is provided by the OM which is derived from the suspended particles and by the reduced compounds derived from the sediment [59,60]. So, it is proposed that in the BMFC the removal of COD in the seawater is due to the speed of precipitation of the OM particles towards the sediment, the removal of OM occurring near the anodic electrode.

\subsection{Electrochemical Tests}

\subsubsection{Polarization Curves}

The maximum power density was $109.6 \mathrm{~mW} / \mathrm{m}^{2}$ and there was a current density of $929.7 \mathrm{~mA} / \mathrm{m}^{2}$ in the BMFC at $10 \mathrm{~cm}$ anode depth and $10 \mathrm{~cm}$ of cathode separation (Figure 4). The highest values observed at these distances between electrodes in both seasons are presented in Table 1. This result indicates that the potential of the anode is more negative with respect to the depth of the electrode, similar to the change in the redox potential existing in the nature of the sediment $[15,61,62]$.

A high density of current and power was observed in the BMFCs in cold fronts from North America (North). This is because the soil is moderately eutrophic or hypereutrophic during this season, there being no further significant differences with respect to the distances between electrodes in the same seasons (Table 1) [9,30].

The values obtained for current and power density (Modelling) are greater than those reported by Erable et al. (2013) who evaluated a stainless steel biocathode at different distances $(10-100 \mathrm{~cm})$, obtaining the maximum power density and current at $10 \mathrm{~cm}$ and observing that at $100 \mathrm{~cm}$ of separation no significant differences were found [10].

Liu et al. (2015), as shown in Table 1, generated a maximum power density of $184 \mathrm{~mW} / \mathrm{m}^{2}$, finding that this value was obtained due to the large surface area of the anode material where microorganisms can adhere more easily and obtain their electrons. They used carbon brushes, normalizing the values obtained with respect to the value of the cathode $\left(6.24 \mathrm{~cm}^{2}\right)$ [23].

Morris et al. (2012) and Majumber et al. (2014) evaluated BMFC with aerated cathodes of carbon paper with Pt and carbon cloth respectively, obtaining lower densities of power and current than those in this study and showing that a floating air cathode of SSME with AC-CB gives better yields [28,29].

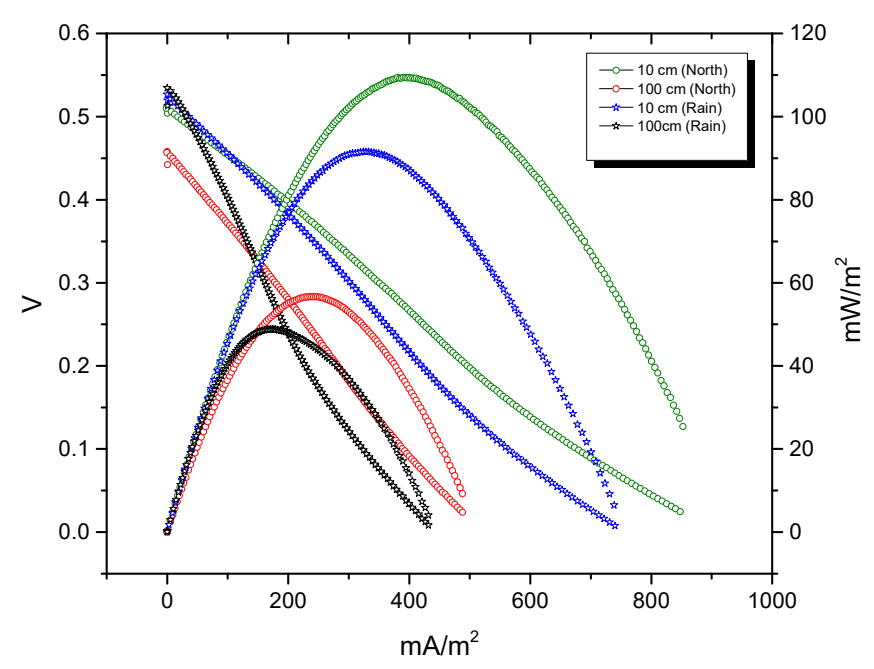

Figure 4. Polarization and power density curves at $10 \mathrm{~cm}$ (anode depth) and separation between the cathode and anode of $10 \mathrm{~cm}$ and $100 \mathrm{~cm}$ (North and Rain). 


\subsubsection{Cyclic Voltammetry (CV)}

The cyclic voltammetry technique helps to examine the electrochemical behavior of the fuel cell and to investigate the presence of electron transporters, mediators and redox activity generated by bacteria.

In this study, it was shown that the maximum current densities varied with respect to the different scanning speeds (Figure 5). However, the voltammograms showed an equal structure, which is why they represent a thermodynamic behavior and similar electron transfer mechanisms of the biofilm without significant influence from the sweep speed of the test [63].

Peaks between $-250 \mathrm{mV}$ and -180 were found. These potentials represent the presence of sulfide formed by reducing sulfur bacteria at the anode as reported by Ryckelynck et al. (2005) [64].

The medium potential of the cyclic voltammetry was $-207 \mathrm{mV}$ versus SCE. This value was close to the redox potential described by C. Aubert et al. (1998) and by K. Sathish-Kumar et al. (2012) of $-215 \mathrm{mV}$, where they mention that this potential is attributed to the extracellular transfer process of electrons carried out outside the cytochrome of sulfate-reducing bacteria, which release the electron to the surface of the electrode [43].

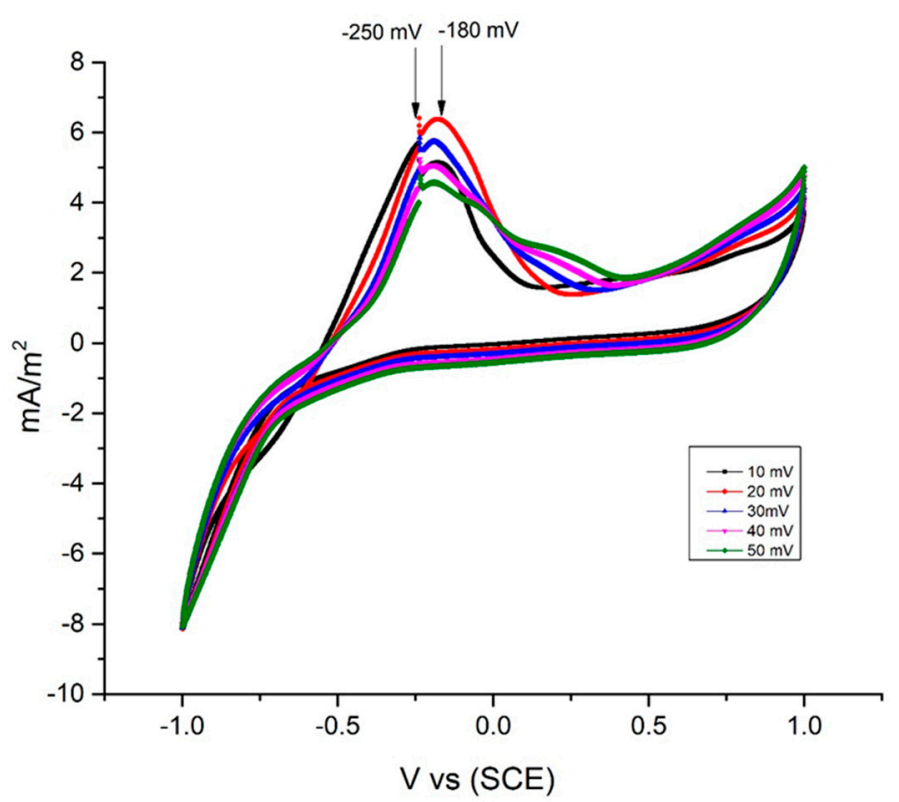

Figure 5. Cyclic voltammetry obtained from the evaluation of the sediment at different sweeping speeds.

\subsubsection{Internal Resistance}

This electrochemical test was carried out to identify the internal resistance in the complete cell, evaluating the cells with the equivalent circuit to obtain an electrochemical parameter as shown in Figure 6. Internal resistance values between $76-130 \Omega$ were obtained and the trend was a higher value observed when placing the electrodes in rain season sediments and distance between them, as shown in Table 1. This phenomenon has been reported in BMFC with more depth, therefore greater resistance. An et al. (2013) evaluated the anode electrode from $2 \mathrm{~cm}$ to $10 \mathrm{~cm}$ depth, obtaining higher densities of power and current at greater depth with an internal resistance of $224 \Omega$ and proposing that the anode is thermodynamically and kinetically favorable for anodophilic and electrophilic species at greater depth $(10 \mathrm{~cm})$. A lower resistance was obtained in this study, mainly due to the material of the SSM $+\mathrm{CA}+\mathrm{CB}$ electrode between 30 and $60 \Omega$, as seen in Figure 6, compared to the resistance of the graphite plates around $100 \Omega[15]$.

A small inductance (L1) was observed at the beginning of the impedance, as seen in Figure 6, this being the vertical line at the beginning of the semicircle, which could be due to the extension of 
the wiring of the electrodes or the presence of low frequencies as mentioned by Min et al. (2012) and Kim et al. (2009). The inductances are small enough that they do not interfere with the current flow, as proposed by Wang et al. (2012) [39,65,66].

The initial resistance (R1) in the equivalent circuit, in addition to being caused by the material of the electrode, was out of phase with the origin at high frequencies because of the reduction of phosphates to iron phosphide (FeP) due to the production of sulfides formed by sulfate-reducing bacteria in marine sediments, as seen in Figure 6. The load transfer resistance (R2) and the constant phase elements $(\mathrm{Q} 2)$ are associated with electron transfer reactions at low frequencies. The interaction of the electrolyte with the metal surface affects the potential due to the iron phosphide formed in the pores. The constant phase element represents the double capacitive layer at the interface between magnitudes of $1840-1570 \mu \mathrm{F} / \mathrm{cm}^{2}$ [67].

The resistance to charge transfer (R3) was one of the main reasons for decreasing cell performance due to the distance of the electrode, as observed by Zhang et al. (2014) in their study [18].

The constant phase element (Q2 and Q3) is used in place of a capacitor to simulate the non-ideal behavior of a distributed capacitance, typically observed in electrodes with porous materials as observed in this study and as proposed by Ramasamy et al. (2008) [68].

The Warburg element (W1) usually occurs at the high frequencies of the system and represents the presence of a simple diffusion. He et al. (2009) propose that this element could be due to the variety of processes that occur in the biofilm [69].
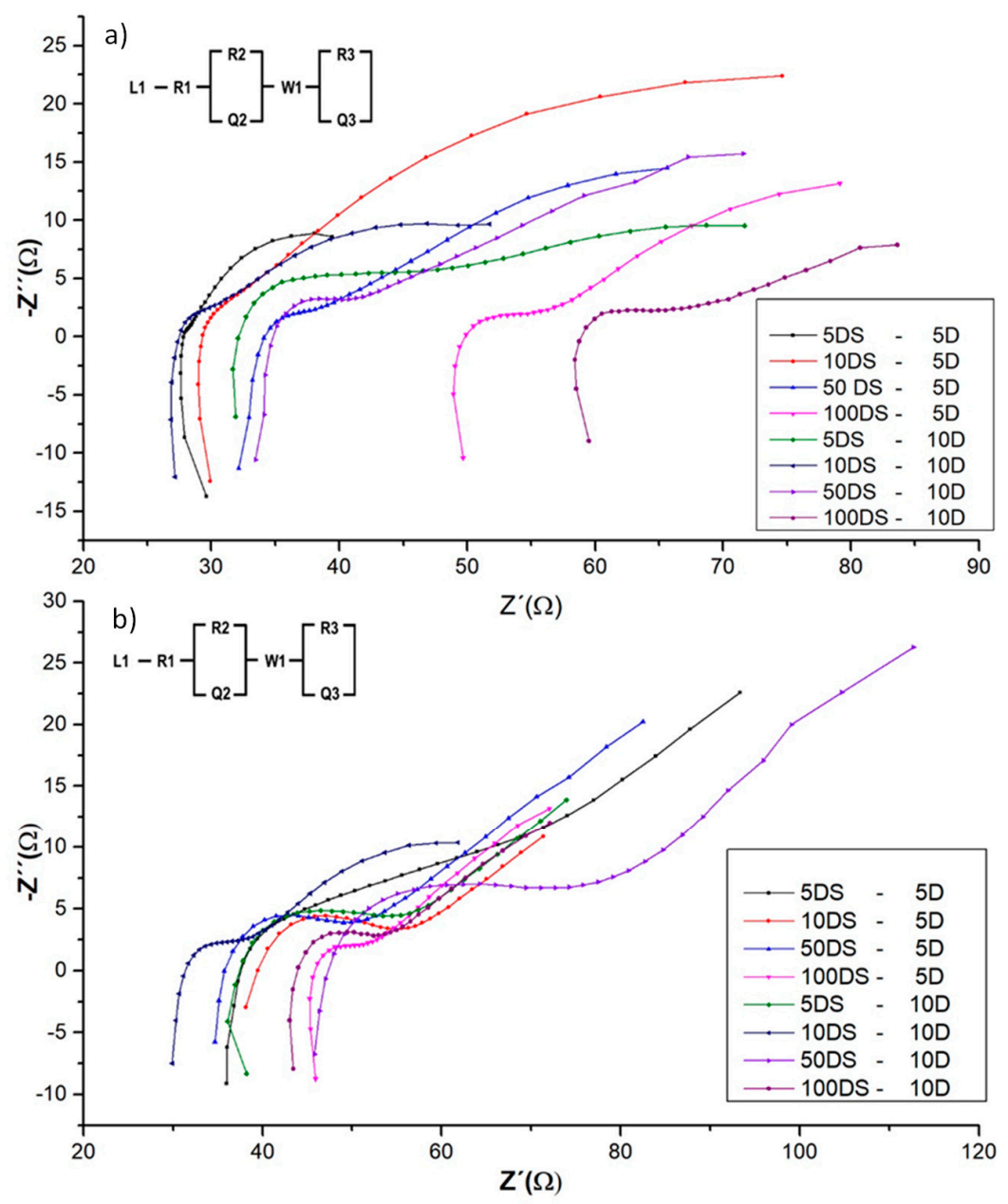

Figure 6. Electrochemical impedance spectroscopy (a) BMFC during weather system from the North and (b) BMFC in Rainy season and equivalent circuit. DS: Distance, D. Depth. 
Table 1. Power density and current density in BMFC.

\begin{tabular}{|c|c|c|c|c|c|c|c|c|c|}
\hline \multirow{2}{*}{ Cathode } & \multirow{2}{*}{ Cathode Distance } & \multirow{2}{*}{ Anode Depth } & \multicolumn{2}{|c|}{ Power Density } & \multicolumn{2}{|c|}{ Current Density } & \multicolumn{2}{|c|}{ Internal Resistance } & \multirow{2}{*}{ Reference } \\
\hline & & & (North) & (Rain) & (North) & (Rain) & (North) & (Rain) & \\
\hline & $\mathrm{cm}$ & $\mathrm{cm}$ & $\mathrm{mW} / \mathrm{m}^{2}$ & $\mathrm{~mW} / \mathrm{m}^{2}$ & $\mathrm{~mA} / \mathrm{m}^{2}$ & $\mathrm{~mA} / \mathrm{m}^{2}$ & $\Omega$ & $\Omega$ & \\
\hline \multirow{8}{*}{ SSME } & 5 & \multirow{5}{*}{5} & $94.1 \pm 3.9$ & $38.6 \pm 5.2$ & $857.5 \pm 9.5$ & $337.7 \pm 9.5$ & $54.2 \pm 2.1$ & $125.8 \pm 6.6$ & \multirow{8}{*}{ This study } \\
\hline & 10 & & $59.6 \pm 0.9$ & $63 \pm 13.2$ & $463.6 \pm 9.5$ & $554.7 \pm 9.5$ & $122.1 \pm 1.5$ & $78.5 \pm 2.3$ & \\
\hline & 50 & & $60.5 \pm 7.5$ & $60.3 \pm 8.8$ & $609.4 \pm 13.1$ & $527.2 \pm 10.8$ & $95.7 \pm 17.4$ & $85 \pm 14.6$ & \\
\hline & 100 & & $60.3 \pm 5.6$ & $46.5 \pm 8.3$ & $589 \pm 13.1$ & $451.7 \pm 9.5$ & $114.6 \pm 1.5$ & $130.8 \pm 18.1$ & \\
\hline & 5 & & $58.1 \pm 10.6$ & $48.6 \pm 2.8$ & $541.8 \pm 13.1$ & $444.5 \pm 19.6$ & $76.3 \pm 19.4$ & $125.1 \pm 16.7$ & \\
\hline & 10 & \multirow{3}{*}{10} & $109.6 \pm 7.5$ & $97.1 \pm 16.5$ & $929.7 \pm 9.5$ & $759.2 \pm 9.5$ & $85 \pm 17.4$ & $89 \pm 8.8$ & \\
\hline & 50 & & $64.8 \pm 0.1$ & $40.8 \pm 1.8$ & $562.1 \pm 10.8$ & $375.1 \pm 6.3$ & $86.3 \pm 15.2$ & $92.6 \pm 8.6$ & \\
\hline & 100 & & $55.8 \pm 9.2$ & $47.8 \pm 8.7$ & $519.6 \pm 10.8$ & $444.2 \pm 19.6$ & $110.5 \pm 6.7$ & $116.5 \pm 12.8$ & \\
\hline Carbon cloth with AC & 15 & 2 & \multicolumn{2}{|c|}{184} & \multicolumn{2}{|c|}{1.54} & \multicolumn{2}{|c|}{80} & [23] \\
\hline Carbon cloth & $N / R$ & 2 & \multicolumn{2}{|c|}{29} & \multicolumn{2}{|c|}{5.625} & \multicolumn{2}{|c|}{141} & [28] \\
\hline Carbon paper with $\mathrm{Pt}$ & 20 & 2 & \multirow{2}{*}{\multicolumn{2}{|c|}{$\begin{array}{l}11.1 \\
31.8\end{array}$}} & \multicolumn{2}{|c|}{0.05} & \multicolumn{2}{|c|}{4050} & [29] \\
\hline Stainless steel plates (Biocathode) & $10-100$ & 10 & & & \multirow{2}{*}{\multicolumn{2}{|c|}{$\begin{array}{l}159 \\
2.32\end{array}$}} & \multirow{2}{*}{\multicolumn{2}{|c|}{$\begin{array}{c}\mathrm{N} / \mathrm{R} \\
20\end{array}$}} & [10] \\
\hline Carbon cloth AC & 0.02 & 0.01 & \multicolumn{2}{|c|}{107.8} & & & & & [30] \\
\hline \multicolumn{9}{|c|}{ SSME $=$ Stainless steel mesh electrodeposition } & \\
\hline
\end{tabular}




\section{Conclusions}

In this study, the maximum power and current density were obtained at $10 \mathrm{~cm}$ of anode depth and $10 \mathrm{~cm}$ distance between electrodes with an internal resistance of $85 \Omega$. However, the BMFC at $10 \mathrm{~cm}$ of anode depth and $100 \mathrm{~cm}$ between electrodes (internal resistance $110.5 \Omega$ ) is well acceptable performance and scaling could be developed with this configuration to be able to use this energy for the benefit of the inhabitants the coast. Finally, the OM in the marine sediment was removed up to $54 \%$ and was mainly composed of aliphatic chains. The stainless steel mesh with electrodeposition $\mathrm{Zn}$-Ni-Co in a floating air cathode is a suitable material for systems in which saline water electrolytes are used, furthermore, it provides adequate conduction and an improvement in the performance of the BMFC.

Author Contributions: N.G.-G.: performed the experiments presented herein and drafted the manuscript. X.D.-B.: supervised the results of this project. D.P.-C. and S.K.-K.: supervised the electrochemical techniques performed in this study. D.V.-L.: provided equipment and knowledge. J.D.-M.: supervised laboratory techniques. L.A.-G. conceived the study, financed the project, supervised the work and the manuscript. All authors participated in the experimental design, evaluation of the data, reading and approval of final manuscript.

Funding: This research received no external funding.

Acknowledgments: Mexican Council for Science (CONACYT) for the financial support granted to carry out this study through grant 426739 awarded for doctoral studies.

Conflicts of Interest: The authors declare that they have no competing interests.

\section{References}

1. Botello, A.V.; von Osten, J.R.; Bouchot, G.G.; Hernández, C.A. Golfo de México: Contaminación e Impacto Ambiental; Universidad Autónoma de Campeche: Campeche, Mexico, 2005.

2. Kanzari, F.; Syakti, A.D.; Asia, L.; Malleret, L.; Piram, A.; Mille, G. Distributions and sources of persistent organic pollutants (aliphatic hydrocarbons, PAHs, PCBs and pesticides) in surface sediments of an industrialized urban river (Huveaune), France. Sci. Total Environ. 2014, 478, 141-151. [CrossRef] [PubMed]

3. Velasco, M.I.; Campitelli, P.A.; Ceppi, S.B.; Havel, J. Analysis of humic acid from compost of urban wastes and soil by fluorescence spectroscopy. Agriscientia 2004, 21, 31-38.

4. Manahan, S.E. Introducción a la Química Ambiental; Reverté, S.A., Ed.; UNAM, México D.F: Mexico City, Mexico, 2007; pp. 61-63.

5. Solis, J.N. Fundamentos de Edafología, 2nd ed.; Universidad Estatal a Distancia: San José, Costa Rica, 1981.

6. Hayes, M.H.B.; Tseng, T.Y.; Wang, M.K. Chemistry of soil organic matter. J. For. Sci. 2007, 22, 215-226.

7. Zhou, Y.-L.; Yang, Y.; Chen, M.; Zhao, Z.-W.; Jiang, H.-L. To improve the performance of sediment microbial fuel cell through amending colloidal iron oxyhydroxide into freshwater sediments. Bioresour. Technol. 2014, 159, 232-239. [CrossRef] [PubMed]

8. Ghangrekar, M.M.; Shinde, V.B. Performance of membrane-less microbial fuel cell treating wastewater and effect of electrode distance and area on electricity production. Bioresour. Technol. 2007, 98, 2879-2885. [CrossRef] [PubMed]

9. Hong, S.W.; Chang, I.S.; Choi, Y.S.; Chung, T.H. Experimental evaluation of influential factors for electricity harvesting from sediment using microbial fuel cell. Bioresour. Technol. 2009, 100, 3029-3035. [CrossRef] [PubMed]

10. Erable, B.; Lacroix, R.; Etcheverry, L.; Féron, D.; Delia, M.L.; Bergel, A. Marine floating microbial fuel cell involving aerobic biofilm on stainless steel cathodes. Bioresour. Technol. 2013, 142, 510-516. [CrossRef] [PubMed]

11. Sajana, T.K.; Ghangrekar, M.M.; Mitra, A. Effect of operating parameters on the performance of sediment microbial fuel cell treating aquaculture water. Aquacult. Eng. 2014, 61, 17-26. [CrossRef]

12. Reimers, C.E.; Tender, L.M.; Ferting, S.; Wang, W. Harvesting energy pro the marine sediment-water interface. Environ. Sci. Technol. 2001, 35, 192-195. [CrossRef] [PubMed]

13. Karra, U.; Huang, G.; Umaz, R.; Tenaglier, C.; Wang, L.; Li, B. Stability characterization and modeling of robust distributed benthic microbial fuel cell (DBMFC) system. Bioresour. Technol. 2013, 144, 477-484. [CrossRef] [PubMed] 
14. An, J.; Nam, J.; Kim, B.; Lee, H.-S.; Kim, B.H.; Chang, I.S. Performance variation according to anode-embedded orientation in a sediment microbial fuel cell employing a chessboard-like hundred-piece anode. Bioresour. Technol. 2015, 190, 175-181. [CrossRef] [PubMed]

15. An, J.; Kim, B.; Nam, J.; Ng, H.Y.; Chang, I.S. Comparison in performance of sediment microbial fuel cells according to depth of embedded anode. Bioresour. Technol. 2013, 127, 138-142. [CrossRef] [PubMed]

16. Cheng, S.; Liu, H.; Logan, B.E. Increased performance of single-chamber microbial fuel cells using an improved cathode structure. Electrochem. Commun. 2006, 8, 489-494. [CrossRef]

17. Finkelstein, D.A.; Tender, L.M.; Zeikus, J.G. Effect of electrode potential on electrode-reducing microbiota. Environ. Sci. Technol. 2006, 40, 6990-6995. [CrossRef] [PubMed]

18. Zhang, X.; Pant, D.; Zhang, F.; Liu, J.; He, W.; Logan, B.E. Long-Term Performance of Chemically and Physically Modified Activated Carbons in Air Cathodes of Microbial Fuel Cells. ChemElectroChem 2014, 1, 1859-1866. [CrossRef]

19. Zhang, X.; Sun, H.; Liang, P.; Huang, X.; Chen, X.; Logan, B.E. Air-cathode structure optimization in separator-coupled microbial fuel cells. Biosens. Bioelectron. 2011, 30, 267-271. [CrossRef] [PubMed]

20. Zhang, X.; He, W.; Yang, W.; Liu, J.; Wang, Q.; Liang, P.; Huang, X.; Logan, B.E. Diffusion layer characteristics for increasing the performance of activated carbon air cathodes in microbial fuel cells. Environ. Sci. Water Res. Technol. 2016, 2, 266-273. [CrossRef]

21. Tender, L.M.; Gray, S.A.; Groveman, E.; Lowy, D.A.; Kauffman, P.; Melhado, J.; Tyce, R.C.; Flynn, D.; Petrecca, R.; Dobarro, J. The first demonstration of a microbial fuel cell as a viable power supply: Powering a meteorological buoy. J. Power Sources 2008, 179, 571-575. [CrossRef]

22. Ewing, T.; Ha, P.T.; Babauta, J.T.; Tang, N.T.; Heo, D.; Beyenal, H. Scale-up of sediment microbial fuel cells. J. Power Sources 2014, 272, 311-319. [CrossRef]

23. Liu, B.; Weinstein, A.; Kolln, M.; Garrett, C.; Wang, L.; Bagtzoglou, A.; Karra, U.; Li, Y.; Li, B. Distributed multiple-anodes benthic microbial fuel cell as reliable power source for subsea sensors. J. Power Sources 2015, 286, 210-216. [CrossRef]

24. Chiou, C.T.; Kile, D.E. Contaminant Sorption By Soil and Bed Sediment; U.S. Department of Interior, U.S. Geological Survey: Reston, VA, USA, 2000.

25. Lowy, D.A.; Tender, L.M. Harvesting energy from the marine sediment-water interface: III. Kinetic activity of quinone-and antimony-based anode materials. J. Power Sources 2008, 185, 70-75. [CrossRef]

26. Rezaei, F.; Richard, T.L.; Brennan, R.A.; Logan, B.E. Substrate-enhanced microbial fuel cells for improved remote power generation from sediment-based systems. Environ. Sci. Technol. 2007, 41, 4053-4058. [CrossRef] [PubMed]

27. Thomas, Y.R.J.; Picot, M.; Carer, A.; Berder, O.; Sentieys, O.; Barrière, F. A single sediment-microbial fuel cell powering a wireless telecommunication system. J. Power Sources 2013, 241, 703-708. [CrossRef]

28. Majumder, D.; Maity, J.P.; Chen, C.-Y.; Chen, C.-C.; Yang, T.-C.; Chang, Y.-F.; Hsu, D.-W.; Chen, H.-R. Electricity generation with a sediment microbial fuel cell equipped with an air-cathode system using photobacterium. Int. J. Hydrogen Energy 2014, 39, 21215-21222. [CrossRef]

29. Morris, J.M.; Jin, S. Enhanced biodegradation of hydrocarbon-contaminated sediments using microbial fuel cells. J. Hazard. Mater. 2012, 213-214, 474-477. [CrossRef] [PubMed]

30. Yuan, Y.; Zhou, S.; Zhuang, L. A new approach to in situ sediment remediation based on air-cathode microbial fuel cells. J. Soils Sediments 2010, 10, 1427-1433. [CrossRef]

31. Zhang, X.; Xia, X.; Ivanov, I.; Huang, X.; Logan, B.E. Enhanced Activated Carbon Cathode Performance for Microbial Fuel Cell by Blending Carbon Black. Environ. Sci. Technol. 2014, 48, 2075-2081. [CrossRef] [PubMed]

32. Dumas, C.; Mollica, A.; Féron, D.; Basseguy, R.; Etcheverry, L.; Bergel, A. Checking graphite and stainless anodes with an experimental model of marine microbial fuel cell. Bioresour. Technol. 2008, 99, 8887-8894. [CrossRef] [PubMed]

33. Hong, S.W.; Kim, H.S.; Chung, T.H. Alteration of sediment organic matter in sediment microbial fuel cells. Environ. Pollut. 2010, 158, 185-191. [CrossRef] [PubMed]

34. Abou-Krisha, M.M.; Rageh, H.M.; Matter, E.A. Electrochemical studies on the electrodeposited Zn-Ni-Co ternary alloy in different media. Surf. Coat. Technol. 2008, 202, 3739-3746. [CrossRef]

35. Abou-Krisha, M.M. Electrochemical studies of zinc-nickel codeposition in sulphate bath. Appl. Surf. Sci. 2005, 252, 1035-1048. [CrossRef] 
36. Lovley, D.R. Microbial energizers: Fuel cell that keep on going. Microbes 2006, 1, 323-329. [CrossRef]

37. Lowy, D.A.; Tender, L.M.; Zeikus, J.G.; Park, D.; Lovley, D.R. Harvesting energy from the marine sediment-water interface II. kinetic activity of anode materials. Biosens. Bioelectron. 2006, 21, 2058-2063. [CrossRef] [PubMed]

38. Mitov, M.; Bardarov, I.; Mandjukov, P.; Hubenova, Y. Chemometrical assessment of the electrical parameters obtained by long-term operating freshwater sediment microbial fuel cells. Bioelectrochemistry 2015, 106, 105-114. [CrossRef] [PubMed]

39. Wang, H.; Ren, Z.; Park, J.-D. Power electronic converters for microbial fuel cell energy extraction: Effects of inductance, duty ratio, and switching frequency. J. Power Sources 2012, 220, 89-94. [CrossRef]

40. American Public Health Association. Standard Methods for Examination of Water and Wastewater; American Public Health Association: Washington, DC, USA, 2005.

41. Kononova, M.M.; Nowakowsky, Z.T.; Newman, D.C.A. Its nature, its role in soil formation and in soil fertility. In Soil Organic Matter; Pergamon Press: New York, NY, USA, 1966.

42. Hach Company. Procedures Manual. Hach DR/890 Colorimeter; Hach Company: Loveland, CO, USA, 2013.

43. Sathish-Kumar, K.; Solorza-Feria, O.; Hernández-Vera, R.; Vazquez-Huerta, G.; Poggi-Varaldo, H.M. Comparison of various techniques to characterize a single chamber microbial fuel cell loaded with sulfate reducing biocatalysts. J. New Mater. Electrochem. Syst. 2012, 15, 195-201.

44. Li, W.-W.; Yu, H.-Q. Stimulating sediment bioremediation with benthic microbial fuel cells. Biotechnol. Adv. 2015, 33, 1-12. [CrossRef] [PubMed]

45. González-Gamboa, N.K.; Valdés-Lozano, D.S.; Barahona-Pérez, L.F.; Alzate-Gaviria, L.; Domínguez-Maldonado, J.A. Removal of organic matter and electricity generation of sediments from Progreso, Yucatan, Mexico, in a sediment microbial fuel cell. Environ. Sci. Pollut. Res. 2017, 24, 5868-5876. [CrossRef] [PubMed]

46. Zhou, Y.-L.; Jiang, H.-L.; Cai, H.-Y. To prevent the occurrence of black water agglomerate through delaying decomposition of cyanobacterial bloom biomass by sediment microbial fuel cell. J. Hazard. Mater. 2015, 287 (Suppl. C), 7-15. [CrossRef] [PubMed]

47. Hidalgo, D.; Sacco, A.; Hernández, S.; Tommasi, T. Electrochemical and impedance characterization of Microbial Fuel Cells based on 2D and 3D anodic electrodes working with seawater microorganisms under continuous operation. Bioresour. Technol. 2015, 195, 139-146. [CrossRef] [PubMed]

48. Poerschmann, J.; Koschorreck, M.; Górecki, T. Organic matter in sediment layers of an acidic mining lake as assessed by lipid analysis. Part II: Neutral lipids. Sci. Total Environ. 2017, 578, 219-227. [CrossRef] [PubMed]

49. Wang, A.; Cheng, H.; Ren, N.; Cui, D.; Lin, N.; Wu, W. Sediment microbial fuel cell with floating biocathode for organic removal and energy recovery. Front. Environ. Sci. Eng. 2012, 6, 569-574. [CrossRef]

50. Chen, Y.; Senesi, N.; Schnitzer, M. Information Provided on Humic Substances by E4/E6 Ratios1. Soil Sci. Soc. Am. J. 1977, 41, 352-358. [CrossRef]

51. Bravo, I.; Potosí, L.M.S. Fraccionamiento del fósforo y correlación con la materia orgánica en dos suelos del departamento del Cauca. Suelos Ecuatoriales 2007, 37, 147-154.

52. Theng, B.K.G. Chapter 12-Humic Substances. In Developments in Clay Science; Theng, B.K.G., Ed.; Elsevier: New York, NY, USA, 2012; Volume 4, pp. 391-456.

53. Gigliotti, G.; Businelli, D.; Giusquiani, P.L. Composition change of soil humus after massive aplication of urban waste compost: A comparison between FT-IR spectroscopy and humification parameters. Nutr. Cycl. Agroecosyst. 1999, 55, 23-28. [CrossRef]

54. Yan, Z.; Song, N.; Cai, H.; Tay, J.-H.; Jiang, H. Enhanced degradation of phenanthrene and pyrene in freshwater sediments by combined employment of sediment microbial fuel cell and amorphous ferric hydroxide. J. Hazard. Mater. 2012, 199-200 (Suppl. C), 217-225. [CrossRef] [PubMed]

55. Mosquera, C.S.; Bravo, I.; Hansen, E.W. Comportamiento estructural de los ácidos húmicos obtenidos de un suelo andisol del departamento del cauca. Rev. Colomb. Quim. 2007, 36, 31-41.

56. Zhao, X.; Wang, X.; Shi, X.; Li, K.; Ding, D. Environmental capacity of chemical oxygen demand in the Bohai Sea: Modeling and calculation. Chin. J. Oceanol. Limnol. 2011, 29, 46-52. [CrossRef]

57. Hocaoglu, S.M.; Orhon, D. Particle size distribution analysis of chemical oxygen demand fractions with different biodegradation characteristics in black water and gray water. CLEAN Soil Air Water 2013, 41, 1044-1051. [CrossRef]

58. Yin, Y.; Zhang, Y.; Liu, X.; Zhu, G.; Qin, B.; Shi, Z.; Feng, L. mporal and spatial variations of chemical oxygen demand in Lake Taihu, China, from 2005 to 2009. Hydrobiologia 2011, 665, 129-141. [CrossRef] 
59. Lein, A.Y.; Kravchishina, M.D.; Politova, N.V.; Savvichev, A.S.; Veslopolova, E.F.; Mitskevich, I.N.; Ul'yanova, N.V.; Shevchenko, V.P.; Ivanov, M.V. Transformation of particulate organic matter at the water-bottom boundary in the Russian Arctic seas: Evidence from isotope and radioisotope data. Lithol. Miner. Resour. 2012, 47, 99-128. [CrossRef]

60. Sajana, T.K.; Ghangrekar, M.M.; Mitra, A. Influence of electrode material on performance of sediment microbial fuel cell remediating aquaculture water. Environ. Eng. Manag. J. (EEMJ) 2017, 16, 421-429.

61. Froelich, P.N.; Klinkhammer, G.; Bender, M.L.; Luedtke, N.; Heath, G.R.; Cullen, D.; Dauphin, P.; Hammond, D.; Hartman, B.; Maynard, V. Early oxidation of organic matter in pelagic sediments of the eastern equatorial Atlantic: Suboxic diagenesis. Geochim. Cosmochim. Acta 1979, 43, 1075-1090. [CrossRef]

62. Wang, Y.; Francis, A.J. Evaluation of microbial activity for long-term performance assessments of deep geologic nuclear waste repositories. J. Nuclear Radiochem. Sci. 2005, 6, 43-50. [CrossRef]

63. Liu, Y.; Harnisch, F.; Fricke, K.; Sietmann, R.; Schröder, U. Improvement of the anodic bioelectrocatalytic activity of mixed culture biofilms by a simple consecutive electrochemical selection procedure. Biosens. Bioelectron. 2008, 24, 1006-1011. [CrossRef] [PubMed]

64. Rickelynck, N.; Stecher, H.A., III; Reimers, C.E. Undestanding the anodic mechanism of seafloor fuel cell: Interactions geochemistry and microbial activity. J. Biochem. 2005, 76, 113-139.

65. Min, B.; Poulsen, F.W.; Thygesen, A.; Angelidaki, I. Electric power generation by a submersible microbial fuel cell equipped with a membrane electrode assembly. Bioresour. Technol. 2012, 118, 412-417. [CrossRef] [PubMed]

66. Kim, J.R.; Premier, G.C.; Hawkes, F.R.; Dinsdale, R.M.; Guwy, A.J. Development of a tubular microbial fuel cell (MFC) employing a membrane electrode assembly cathode. J. Power Sources 2009, 187, 393-399. [CrossRef]

67. Castaneda, H.; Benetton, X.D. SRB-biofilm influence in active corrosion sites formed at the steel-electrolyte interface when exposed to artificial seawater conditions. Corros. Sci. 2008, 50, 1169-1183. [CrossRef]

68. Ramasamy, R.P.; Ren, Z.; Mench, M.M.; Regan, J.M. Impact of initial biofilm growth on the anode impedance of microbial fuel cells. Biotechnol. Bioeng. 2008, 101, 101-108. [CrossRef] [PubMed]

69. He, Z.; Mansfeld, F. Exploring the use of electrochemical impedance spectroscopy (EIS) in microbial fuel cell studies. Energy Environ. Sci. 2009, 2, 115-119. [CrossRef] 